Check for updates

New York

Cite this as: $B M J 2020 ; 371: \mathrm{m} 3908$ http://dx.doi.org/10.1136/bmj.m3908 Published: 07 October 2020

\section{Covid-19: Group of UK and US experts argues for "focused protection" instead of lockdowns}

\author{
Jeanne Lenzer
}

Thousands of medical practitioners and public health scientists have signed a declaration arguing for an alternative public health approach to dealing with covid-19.

The Great Barrington Declaration, ${ }^{1}$ published on Monday 5 October, was drawn up by three epidemiologists and public health experts from Harvard, Oxford, and Stanford universities, who describe their approach as "focused protection" of the people most at risk.

As of Wednesday 7 October almost 6300 medical practitioners and public health scientists from the US, the UK, and other nations had signed the declaration.

The authors-Martin Kulldorff, professor of medicine at Harvard, Sunetra Gupta, professor of theoretical epidemiology at Oxford, and Jay Bhattacharya, professor of medicine and economics at Stanford-said that because older people were 1000 times more likely to die of covid-19 than younger people, an "age stratified" approach could allow resources to be focused on older and high risk patients, while allowing younger and healthier people to attend school and keep businesses open.

They argue that focused protection would reduce the "collateral harms" of lockdown, including deaths from suicides, reduced childhood immunization, and increases in domestic violence.

Gupta said that widespread starvation was another serious consequence of lockdowns-a concern underscored by a report from the charity Oxfam, ${ }^{2}$ which found that border closures, curfews, and travel restrictions had caused breaks in the food supply that threatened to cause 12 ooo deaths a day worldwide, exceeding the 10 ooo deaths a day recorded from covid-19 in April. ${ }^{3}$

Kulldorff said that, with focused protection, low risk people could remain active and that this would help communities reach herd immunity sooner, which could shorten the duration and harms of lockdowns. ${ }^{4}$ Herd immunity, he said at a meeting in Great Barrington, Massachusetts, "is not a strategy-but a biological reality that will arrive sooner or later, either naturally or through a vaccine, or both."

He defended the Swedish approach, saying that "schools were never closed for children aged 1 to 15 , with zero covid-19 deaths ... and the United States has now passed Sweden in terms of deaths per million inhabitants, despite Sweden having an older, more high risk population." 5

\section{Benefits and harms}

On Monday the declaration's authors met with Alex Azar, US secretary of health and human services, and Scott Atlas, an adviser to President Trump, for what Kulldorff described as a "very good discussion." 6

However, Stefan Baral, a physician epidemiologist and associate professor at Johns Hopkins University, said he was concerned that the meeting had taken place. Baral explained that, while he generally agreed that lockdowns were causing serious harms, he had declined to sign the declaration because it did not address the concrete steps needed to assist the most vulnerable people.

Baral told The BMJ that three steps must accompany any loosening of restrictions: firstly, the removal of leave for people affected by covid-19; and lastly, housing support for such people in multigenerational households.

“Sweden instituted paid leave from day 1," he said. "You can call in sick and know that you are going to be able to eat that night. In the US, if you call in sick, you and your family may not eat."

Bhattacharya, one of the authors, said that he welcomed such criticisms, as he hoped that the declaration would be just the beginning of an important dialogue about the benefits, and the harms, of public health interventions.

Great Barrington declaration and petition. 4 Oct 2020. https://gbdeclaration.org/.

2 Oxfam media briefing. The hunger virus: how covid-19 is fuelling hunger in a hungry world. 9 Jul 2020. https://oxfamilibrary.openrepository.com/bitstream/handle/10546/621023/mb-the-hunger-virus-090720-en.pdf.

3 Ahmed K. Hunger could kill millions more than covid-19, warns Oxfam. Guardian 2020 Jul 9. https://www.theguardian.com/global-development/2020/jul/09/hunger-could-kill-millions-more-than-covid-19-warnsoxfam.

4 Kulldorff M. Delaying herd immunity is costing lives. American Institute for Economic Research. 31 Aug 2020. https://www.aier.org/article/delayingherd-immunity-is-costing-lives/.

5 Aschoff N. We need a radically different approach to the pandemic and our economy as a whole. Jacobin 2020 Sep 19. https://jacobinmag.com/2020/09/covid-19-pandemic-economy-us-response-inequality.

6 Hellmann J. Trump health official meets with doctors pushing herd immunity. The Hill 2020 Oct 5. https://thehill.com/policy/healthcare/519727-trumphealth-official-meets-with-doctors-pushing-herd-immunity.

This article is made freely available for use in accordance with BMJ's website terms and conditions for the duration of the covid-19 pandemic or until otherwise determined by BMJ. You may use, download and print the article for any lawful, non-commercial purpose (including text and data mining) provided that all copyright notices and trade marks are retained. any barriers to accessing healthcare; secondly, paid 